\title{
The Effectiveness of the Statistics Learning Model Based on Constructivist to Improve the Statistics Learning Outcomes of Students in the Building Engineering Education Study Program
}

\author{
Enny Keristiana Sinaga ${ }^{1, *}$ Abdul Muin Sibuea ${ }^{2}$ Julaga Situmorang ${ }^{3}$ \\ ${ }^{1}$ Building Engineering Education Study Program, Universitas Negeri Medan \\ ${ }^{2}$ Electrical Engineering Education Study Program, Universitas Negeri Medan \\ ${ }^{3}$ Educational Technology Study Program, Universitas Negeri Medan \\ * Corresponding author. Email: ennysinaga@unimed.ac.id
}

\begin{abstract}
This research aims to produce a statistics learning model based on constructivist and the effectiveness of learning model that are developed in order to improve the result in learning statistics for the students. This research is a research and development (R\&D) with one group pretest-posttest design. This research is done in the study program of education of Building Engineering for the academic year in 2020/2021. Analysis of the effectiveness of learning model is developed done in twice trials, those are trial for small group and trial for large group. The result of the paired sample T-test (sig.2tailed $<0.05$ ) show that there is differences in the learning result before and after the students are taught by using statistics learning model based on constructivists in significantly due to the influence of model application of that is developed in the activity of learning statistics that is held. The result of the effectiveness with testing N-Gain that is normalized show that the implementation of the statistic learning model based on constructivist in the test of small group is $58.05 \%$ and the test of large group is $71.18 \%$ in order to improve the result of learning statistics for the students.
\end{abstract}

Keywords: Constructivist, Development, Learning Model, Statistics.

\section{INTRODUCTION}

Universitas Negeri Medan (Unimed) is an Educational Institution of education personnel (LPTK) that produces candidates of professional teachers. Study program of education of Building Engineering (study program of $\mathrm{PTB}$ ) is one of the study programs that is in under the Department of education of Building Engineering, in the Faculty of Engineering from Universitas Negeri Medan.

Study program of PTB has the aim to produce education personnel (teachers) vocational and technicians, and young researchers who are excellent, professional, characteristics and able to develop innovative work through research in the field of building engineering. So that Unimed as LPTK will produce candidates of professional teachers.

In the Law of the Republic of Indonesia Number 14 Article 8 in the year of 2005 about teacher and Lecturer, it is stated that teacher is obligatory to has qualification of academic, competence, educator certificate, physically and mentally healthy, and has the ability to realize goal of national education. The qualification of academic as is referred in Article 8 is obtained through a higher education of undergraduate program or a four-diploma program. So that the graduates of study program of PTB to become a teacher must have an educator certificate in the form of certificate that is obtained after the students have completed the period of his or her study. One of the requirements to get this educator certificate, the students must make a final assignment/thesis. In making the final assignment thesis, the students are expected to have the ability to use a scientific approach to solve a problem. In solving problem, statistics play a role as a tool a of planning, collecting, analyzing, interpreting, and presenting data so that producing decision that is very important for the development for IPTEK. 
Furthermore, according to Law Number 14 Article 10 verse 1 in the year of 2005 about Teacher and Lecturer, it is said that competence of teacher includes competence of pedagogic, competence of personality, competence of social, and competence of professional that are obtained through professional education. Standard of teacher competency is indicator that can be used as a measure of the characteristics of teachers who are considered professionally competent. Competence is a set of knowledge, skill, and behavior that must be possessed, internalized, and mastered by the teachers or lecturers in doing professional duties (Law Number 14 Article 1 verse 10 in the year of 2005 about Teacher and Lecturer). Therefore, teacher competency must be improved to respond to changing times.

To improve teacher competency, a teacher is required to innovate and reform in learning [1]. Innovation and learning reform can be done by the teachers with doing research in the field of education, either classroom action research or development research. It means that research in the field of education is inevitability that must be done as an effort to increase teacher competency. The results of improvement of this teacher competency can be utilized to compile a profile (valuation) of teacher performance which is part of the system of education evaluation. Based on the explanation above, so the students in the study program of PTB as candidates of teachers in the future must be able to understand the principles and interpret the results of educational research for teaching purposes through learning statistics.

Study program of education of Building Engineering (PTB) in the Faculty of Engineering from Universitas Negeri Medan makes the subject of statistics as one of the compulsory subjects that must be taken by the students. The implementation in the subject of statistics has four target aspects that are wanted to be achieved, those are: giving provision of knowledge about theory of statistics to the students, giving provision of practical skills in the form of calculations of statistics, giving description and experience on how to solve problems in daily life about the problem they is faced, and training the students to be able to communicate the results of their study, either in writing in the form of a written report or orally [2]. Therefore, it is hoped that with this subject of statistics, the students can explore quantitative information and qualitative information. Through statistics analysis, it will be obtained a description of the situation, condition or fact and also give a conclusion that is reasonable. So that the students can produce a conclusion that is reasonable, it is needed an ability to inductive reasoning.

In fact, the facts on the ground states that the ability of inductive reasoning of the students in the study program of PTB still relatively low. Based on the result of the analysis the answers of the students that are obtained through a testing ability of inductive reasoning that involve 23 students in the study program of education of building engineering from Universitas Negeri Medan shows that the average score of the achievement of the ability of the students inductive reasoning reach 18.22 with a standard deviation of 7.01 from the ideal maximum score of 60 . The level of the ability of the students' inductive reasoning is $30.37 \%$. These results conclude that the ability of the students' inductive reasoning is low, so those things cause low the result of learning from the students.

There are several things that are suspected of causing the low of the ability of the inductive reasoning in the program study of PTB, those are one of the expository methods that is often used in the class. That method is suspected not to support to improve the ability of the students' inductive reasoning. Most of the student study statistics just to follow what is taught by the lecturer without them understand it. Learning Expository is a form of learning approach that is oriented to the lecturer. It is said that because in this strategy the lecturer plays a very dominant role. According to Sanjaya which is meant by the expository method is "the method that is used by the teacher in teaching the whole concept, facts and rules of mathematics to the students, while the students listen and ask questions if they do not understand what has been explained by the teacher" [3]. Learning the expository method can direct learning statistics into learning to memorize formula, using formula, and copying what the lecturers do to solve the problems. In other words, it can be concluded that during the process of learning statistics, lecturer use deductive reasoning.

The main elements in learning are individuals as learning participants, needs as a source of encouragement, situation of learning, which give the possibility of learning activities. Thus, the manifestation of learning or the act of learning are expressed in the form of changes in behavior. To enable the learning process to occur to the students, then it will be done a series of activities that have been designed that are called by learning. If it is seen from the learning activities in the classroom, in fact that the lecturers are more active than their students. Learning Statistics in the classroom tends to be centered on the lecturer and the students only accept what is given by the lecturer without understanding and knowing the meaning of what is learned. As a result, the students easily forget and cannot use it in their lives.

Some of the weaknesses of the students in interpreting statistical material lie in: classifying the types of the data of statistics, representation of data of statistics, measure of data of statistics, sample as population representation, and testing hypothesis. For example, the students are still weak in recognizing or categorizing data, whether the data is quantitative or qualitative data, discrete or continuous, nominal, ordinal, interval or ratio and know how to testing hypotheses and the meaning of the results of testing hypothesis based on 
the data of statistics. This case is a basic problem in studying the subject of statistics.

The weakness of students in recognizing and classifying types of data of statistics are also shown by Maryati and Priatna that the students have difficulty recognizing and classifying types of data and displaying them on graphs or tables; lack of understanding of how to make accusations; still experiencing confusion in drawing conclusions, compiling evidence, giving reasons or evidences for the correctness of the solution; poorly understand correctly draw conclusions from statements; understand in checking the validity of the argument; and do not know how to find patterns or properties of mathematical phenomena to make generalizations [4]. The results of their research are intended as one of references in determining and defining in the learning methods that will be applied so that the difficulties of the students can be minimized and students' inductive reasoning can be improved.

Learning statistics is essentially about learn to draw conclusion. The problem that is quite complicated but it is the main requirement in statistics analysis is drawing conclusions [5]. Therefore, learning statistics is directed to improve the students' ability to reason, especially inductive reasoning. Based on the problems that are mentioned above, so it is necessary to make a change in the study of statistics to improve the quality of learning in this case is an effort to improve the ability of the students' inductive reasoning.

The ability of the Inductive reasoning in general plays a role in the formation of think logically and systematic skills which are the purpose of giving the subject of statistics. The aim of learning statistics is that students understand statistics very well so that they can get information from data that exist, criticize and make decisions based on that information and aim to develop research skills [6]. This is relevant to the one of the main parameters for each qualification in the KKNI, that is science is described as a system based on scientific methodology to build knowledge through the result of the research in a body of knowledge. Continuous research that is used to build a science must be supported by data records, observations and measurable analysis and aim to increase the human in understanding about natural phenomena and social phenomena. Related to that things, so the students are encouraged to discover, do, and experience contextually by using the resources that they have and the surrounding environment. Learning is more meaningful, because the students directly "do (doing)" and "experienced" themselves an activity (learning), the lecturer only gives a conducive space and facilitates the realization of meaningful experiences for the students. Thus, the students become "subjects", not "objects" in expressing opinions and problem-solving skills. It means that learning will be centered on the students and the students can be motivated by growing their potential in a variety of ways.

Constructivist learning is a process of assimilating and linking the experiences or lessons learned with the understanding they already have, so that their knowledge can be developed [7]. Teaching according to constructivism is not an activity of transferring knowledge from the teacher to students, but an activity that allows the students to build their own knowledge. The students own selves that must interpret what has been learned or taught by adjusting to their experiences. Thus, according to this theory, things that are taught by the teacher must not have to be understood by the students. The understanding of the students may different from the teacher. So it can be said that the right to determine the knowledge that exists in a person is the individual himself or herself, not other people [8].

Constructivist is a theory that comes from the discipline of philosophy. Constructivist can influence by discipline Piaget's cognitive psychology that is concerned with psychological mechanisms that encourage the formation of personal knowledge and social psychology. Vygotsky which leads to social skills to learn with friends, lecturers, and experts. Both the perspectives together imply the importance of the activeness of the students in learning. Both emphasize action on object, the difference is that Piaget emphasizes the importance of individual activity in doing actions to the object, while Vygotsky emphasizes the importance of the sociocultural environment in doing action to the object [9].

Based on the opinions of the experts above, it can be concluded that learning constructivist is the basis of contextual thinking, learning that emphasizes more on the processes and freedom in exploring knowledge and efforts in constructing experiences. In the learning process, it also gives opportunities for the students to express their ideas in their own language, to think about their experiences so that the students are encouraged to do the reasoning process. Through this reasoning process, the problems can be solved. Thus it can be said that constructivist give a positive impact to the students. According to Subarinah, the advantages of the constructivism approach in the learning are : (1) it can train the students to think creatively in addressing problems, (2) it can improve learning comprehension for the students, (3) it can grow an active attitude and participatory to the students, and (4) it can grow an attitude of cooperation and improve the competitive spirit of the students [10]. Based on the description of positive impact from learning this constructivist then it can be concluded that the application in the form of based on the learning constructivist according to implementation in the program study of PTB from Universitas Negeri Medan. But, in addition to having the advantages of the constructivist approach, it also has disadvantages, those are: (1) the Students still have difficulty in finding their 
own answers, (2) it takes a long time, especially for weak students, (3) for the smart students sometimes are not impatient in waiting for their friends that have not finished [11]. This are in line with the problems that are faced by students, that is the students have difficulty in interpreting the material of statistics so that the students tend to be unable to finish or to solve the problems. Based on that matter, it can be concluded that the ability of the students' inductive reasoning is still low, while the ability of the inductive reasoning is the goal in the subject of statistics. Therefore, it is necessary to develop a statistics learning model that can improve the result of learning statistics of the students.

\section{METHOD}

This research is a Research \& Development (R\&D) with reference to the modification of the Borg \& Gall model which are adapted of the Dick and Carey model [12].

Based on the steps of developing the Borg \& Gall model which are adapted of the Dick and Carey model, the following diagram is a flow of procedure in the research of a statistics learning model based on constructivist learning model as it is presented in the Figure 1.

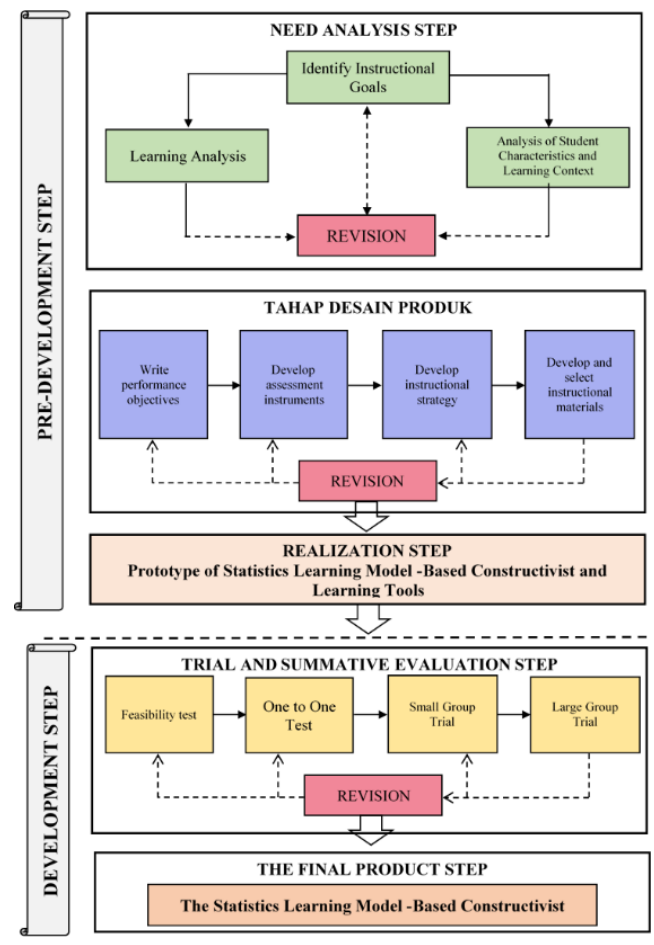

Figure 1. The Procedures of Research and Development for the Statistic Learning Model Based on Constructivist (Adapted of Gall, D., Meredith D., Joyce, P. Gall., Walter, R. Borg. 2007:590
The place of research trial for the development of the statistic learning model based on constructivist is done in the Department of education of Building Engineering in the Faculty of Engineering from Universitas Negeri Medan North Sumatra. The subject of the testing feasibility (testing expert) is the experts at the Universitas Negeri Medan (Unimed). The selection of expert subjects are done purposively by considering competence, ease of communication and experience in their respective fields.

The subject of the research of the effectiveness of the research product is the students of the study program of education of Building Engineering from Universitas Negeri Medan that take the subject of statistics. There participants in the subject of statistics are 26 people and 1 person as a lecturer in the subject of statisticStyles can be applied using the style palette available within the template. To activate it the press Ctrl+Shift+s. Apply the style as required based on the content and context. (Please don't highlight your text in yellow.)

\section{RESULT AND DISCUSSION}

The effectiveness of the statistics learning model based on constructivist is determined by the impact of learning or the result of learning in the aspects of cognitive. The result of the testing effectiveness, either in limited trials or expanded trials, these indicators fulfill the criteria of effectiveness. Analysis of product effectiveness on indicators of learning impact, that is the result learning of the students that are obtained from the post-test. The Data analysis uses a tool of SPSS with requirements of statistics for testing normality and homogeneity. The results of testing normality and homogeneity either in testing small group or testing large group show significant values $>0,05$. Then the analysis is said that qualify statistic. The summary of the results of the testing normality and homogeneity of the data result in learning of small group trials and large group trials are as in the following Table 1.

The results of the analysis of the learning impact in the small group trials and large group trials are shown in the Table 2. The level of mastery of the students competencies are shown from the acquisition of scores on the aspect of cognitive. The acquisition of cognitive scores is converted into a value with a range from 0 to 100. Its aim is to be able to classify the levels of student competency into competent categories or incompetent categories in the sheet of final score. While the level of change in student learning after the treatment is seen the difference in the average of scores of the result in learning between scores before treatment (pretest) and scores after treatment (posttest). The treatment that is referred in here is the application of the statistic learning model based on constructivist in the activity of learning statistics. 
Table 1. The Results Of Testing Normality And Homogeneity

\begin{tabular}{|c|c|c|c|c|}
\hline \multirow{2}{*}{ Test } & \multicolumn{2}{|c|}{ The Result of Small Group Trial } & \multicolumn{2}{c|}{ The Result of Big Group Trial } \\
\cline { 2 - 4 } & Normality & Homogeneity & Normality & Homogeneity \\
\hline Pre-test & 0,200 & \multirow{2}{*}{0,140} & 0,072 & 0,325 \\
\hline Post-test & 0,200 & & 0,130 & \\
\hline
\end{tabular}

Table 2. The Differences in The Average of Scores

\begin{tabular}{|c|c|c|c|}
\hline \multirow{2}{*}{ Trials } & \multicolumn{2}{|c|}{ Average of Scores } & \multirow{2}{*}{ Differences in The Average } \\
\cline { 2 - 3 } & Pretest & Posttest & 36,16 \\
\hline Small Group & 37,71 & 73,87 & 44,47 \\
\hline Big Group & 36,55 & 81,71 & \\
\hline
\end{tabular}

The differences in the average of scores between the scores of pretest and the scores of posttest in the small group trials and large group trials are very significant. However to test the truth of the existence of a significant difference, then the next test uses a paired two-sample ttest (paired t-test) with SPSS. The results of testing $t$ are used to know the differences in the data that is analyzed so that the conclusions that are obtained are $\mathrm{H}_{0}$ is rejected and $\mathrm{H}_{\mathrm{a}}$ is accepted. It is done by Siregar I, I Budiyono, and I Slamet, in their research search the differences in the level of intelligence in learning mathematics, the sig. value on the $\mathrm{t}$ test $<0.05$, then it is concluded that $\mathrm{H} 0$ is rejected and $\mathrm{Ha}$ is accepted [13].

The findings in this research shows that the p-value or the score of probability (sig.2-tailed) the results of learning in the domain of cognitive is smaller than the score of Alpha (alpha value, 5\%). The results of the analysis of the different tests (t-test) that has been done that is presented in the Table 3 .

Table 3. The Results of T-Test

\begin{tabular}{|c|c|c|}
\hline Trials & Sig.(2-tailed) & Description \\
\hline Small Group & 0,000 & $\mathrm{H}_{0}$ Rejected and Ha Accepted \\
\hline Big Group & 0,007 & $\mathrm{H}_{0}$ Rejected and Ha Accepted \\
\hline
\end{tabular}

Based on the results of the analysis of learning impact that is summarized in Table 3, it obtains sig.(2-tailed) in the t-test $<0.05$ indicate that there is differences in the result of learning. The differences in the result of learning of the student before and after the students are taught with the statistics learning model based on constructivist at the level of significant is 5\%. It means that the average of the result in learning of the students after being taught with statistics learning model based on constructivist are better than the average of the result in learning of the students before being taught with the statistics learning model based on constructivist with each differences in the average that are presented before in Table 3.

Table 4. The Average That Is Normalized Gain scores
Furthermore, to see the effectiveness of the statistics learning model based on constructivist, it can be known by the testing $\mathrm{N}$-Gain that is normalized in the aspect of cognitive. The testing $\mathrm{N}$-Gain that is normalized is obtained from the calculation of the difference between the scores if pretest and posttest. The results of the testing $\mathrm{N}-$ Gain then are compared between before and after treatment. Then it is calculated the average gain of the scores to be able to conclude that it is included in the high, medium or low category. The criteria of the effectiveness in this research refers to the average of scores that are normalized Gain, which is in the medium category. The results in the analysis of the learning impact that have been done and presented in Table 4.

\begin{tabular}{|c|c|c|c|c|c|}
\hline \multirow{2}{*}{ Trials } & \multicolumn{2}{|c|}{ Average } & \multirow{2}{*}{ Gain } & N-Gain & Category \\
\cline { 2 - 5 } & Pretest & Posttest & & Medium \\
\hline Small Group & 37,71 & 73,87 & 36,16 & 58,05 & High \\
\hline Big Group & 36,55 & 81,71 & 44,47 & 71,18 & . \\
\hline
\end{tabular}


Table 4 shows that in the small group trials, N-Gain is in the medium category (30 N-Gain 70), while in the large group trials, N-Gain is in the high category $(\mathrm{N}-\mathrm{Gain}<70)$. Based on the results of the testing N-Gain either in small group and large group trials, it can be concluded that the implementation of the statistic learning model based on constructivist and the products for learning statistics that are developed effectively used in order to improve the ability of the students inductive reasoning which are the result of learning that want to be achieved after learning statistics in class has finished.

Learning is said to be effective if it reaches the desired target, either the aims of learning or the result of learning of the students that are maximum. The findings in this research shows that the implementation of the statistic learning model based on constructivist that are developed can give a very positive impact to the increasing of the ability of students' inductive reasoning which are the result of learning that want to be achieved after the lesson of statistics in the class has finished. This finding is in line with the findings of Setyaningsih (2009) who conclude that there is an increase in the students' critical and creative thinking skills in solving basic introductory mathematics problems through a constructivist-based on learning approach. Fitri says that there is an increase in the ability to understand mathematical concepts and student activities through a constructivism-based learning approach [14].

Another finding from this research is that in general, the students are active in following the learning steps that are in accordance with the syntax of the statistic learning model based on constructivist. Besides that, there is an increase in discussion activities either individually or in groups, collecting assignments, and using various learning resources. So that the application of the statistics learning model based on constructivist can increase student's activity in learning statistics. This result is in line with the research results of Micael Sri Rudiyanto (2006) that concluded that the learning model with constructivism strategy has a positive influence on the student's activity in learning [15]. The results of research by Supriyadi and Fatmah AR. Umar (2014) says that the learning model with a constructivist approach is proven to increase motivation, interaction, creativity, reasoning, social sensitivity, giving and receiving other people's opinions, and the students' democratic attitudes in learning [16].

According to the constructivist view, learning objectives will be achieved, if the students build their knowledge in learning. Therefore, effectiveness is also influenced by the student activities in learning. This is in line with the opinion of Eggen and Kauchak (2006) who states that learning is said to be effective, if the students are actively involved in organizing and finding information (knowledge) and the relevance of the information that is provided [17]. The students do not only passively accept the knowledge that is given by the lecturer. The students who must actively develop their knowledge and must be responsible for the result their learning. Learning is more directed at discovery learning and the concept of meaningful learning, that is the learning process that occurs when the students are not presented with information directly but the students are required to organize their understanding of the information independently. The result this learning like this not only improve students' understanding and competence, but also improve their ability of reasoning. Thus, in learning is necessary to pay attention about how the students are involved in organizing lessons and their knowledge. Therefore, the more active students are greater the achievement of learning competencies, so that learning will be more effective.

\section{CONCLUSION}

The statistics learning model based on constructivistlearning and its learning tools in the study program of education of Building Engineering (PTB) fulfil the criteria of effective is used in the learning statistics to be used in order to improve the ability of students' inductive reasoning which are the result of learning that want to be achieved after the lesson of statistics in class has finished, it is shown by the achievement of student learning competencies in small group trials and large group trials.

\section{REFERENCES}

[1] Prensky, M. "Digital Natives, Digital Immigrants". On The Horizon MCB University Press, 2001

[2] Sundayana, R. "Pengaruh Perkuliahan Statistika Berbantuan Ms. Excel Dan Spss Dengan Model Pe,Belajaran Tutorial Terhadap Kemampuam Pemecahan Masalah Dan Komunikasi Matematis". Penelitian Terhadap Mahasiswa Program Studi Pendidikan Matematika STKIP Garut . Bandung: Universitas Pendidikan Indonesia, 2012

[3] Sanjaya, W. "Strategi Pembelajaran". Jakarta: Kencana Prenada Media Grup, 2006

[4] Maryati, I., \& Priatna, N. Analisis Kesulitan Dalam Materi Statistika Ditinjau dari Kemampuan Penalaran dan Komunikasi Statistis. Jurnal PRISMA Universitas Suryakancana. Vol. VI No. 2, 173-179, 2017

[5] Aunuddin. "Statistika : Rancangan dan Analisis Data. Bogor: IPB PRESS, 2005

[6] Rumsey, J. D. Statistical Literacy as a Goal for Introductory Statistics Courses. Journal of Statistics Education Volume 10, Number 3, 1-12, 2002

[7] Cahyo, A. N. "Panduan Aplikasi Teori-Teori Belajar Mengajar Teraktual dan Terpopuler". Yogyakarta: Diva Press, 2013 
[8] Yamin, M. "Desain Pembelajaran Berbasis Tingkat Satuan Pendidikan”. Jakarta: Gaung Persada Press, 2008

[9] Suryaningsih, N., \& Kusmana, S. Pengembangan Bahan Ajar Karya Tulis Berbasis Pendekatan Konstruktivisme. Jurnal Tuturan. Vol 7, No. 2, 884894, 2018

[10] Subarinah, S. "Inovasi Pembelajaran Matematika SD”. Jakarta: Depdiknas, 2006

[11] Baharuddin, \& Wahyuni, E. N. "Teori Belajar dan Pembelajaran”. Yogyakarta: ar_Ruzz Media, 2015

[12] Gall, M., Gall, J. P., \& Borg, W. R. "Educational Research". 8th Edition. New York: Longman, 2003

[13] Siregar, I. I., Budiyono, \& Slamet, I. Team Assisted Individualization (TAI) in Mathematics Learning Viewed from multiple Intelligences. Journal of Physics: Conf. Series 1108 (2018) 012073 DOI:10.1088/1742-6596/1108/1/012073, 1-6, 2018

[14] Fitri, R. (2017). Perangkat Perangkat Pembelajaran Berbasis Pendekatan Konstruktivisme Untuk Meningkatkan Kemampuan Pemahaman Konsep Pada Materi Persamaan Lingkaran. Jurnal JNPM (Jurnal Nasional Pendidikan Matematika. Vol 1. No 2, 241-257, 2017

[15] Rudiyanto, M. S. Pengembangan Model Pembelajaran Metamatika Volum Benda Putar Berbasis Teknologi dengan Strategi Konstruktivisme Student Active Learning Berbantuan CD Interaktif Kelas XII. Semarang: Program Pendidikan Matematika Pascasarjana Universitas Negeri Semarang, 2006

[16] Supriyadi, \& Umar, F. A. Pengembangan Model Pembelajaran Keterampilan Menulis Karya Ilmiah Berpendekatan Konstruktivisme. Gorontalo: Universitas Negeri Gorontalo, 2004

[17] Eggen, P. D., \& Kauchak, D. P. "Strategies and Models for Teachers : Teaching Content and Thinking Skills". 6th Edition. Boston: Allyn \& Bacon, 2012 